Ethiopian Journal of Environmental Studies \& Management 7(2): 202 - 209, 2014.

ISSN:1998-0507

doi: http://dx.doi.org/10.4314/ejesm.v7i2.12

Submitted: December 16, 2013

Accepted: March 13, 2014

\title{
URBAN SOCIO-ECONOMIC DEVELOPMENT AND INTRA-CITY TRAVEL IN OGUN STATE, NIGERIA
}

\author{
SOLANKE, M.O. \\ Department of Geography and Regional Planning, Olabisi Onabanjo University \\ P.M.B. 2002 Ago-Iwoye, Nigeria \\ Email: solankeolayiwola@yahoo.com
}

\begin{abstract}
This study is on influence of socio-economic development of urban centers on intra-city trip generation in Ogun state, Nigeria. The proportion of the aggregate socio-economic variables in each city was used to rank the cities in hierarchical order of development while the average household trip per week was used to rank cities on trip generation. Spearman rank correlation was used to establish nature and extent of relationship between level of urban development and frequency of trip generation of urban centers. The urban centers exhibit hierarchical development pattern both in level of development and trip generation. Abeokuta dominates the distribution of socio-economic variables with aggregate average of $31.22 \%$. This is followed by ljebu-Ode (14.41\%) and Sagamu (10.33\%). In the same manner, Abeokuta has the highest average of household trip generation in the state. ljebu-ode and Sagamu followed with 43 trips per week each. There is a significant high positive correlation coefficient $(r=0.75, p \leq 0.01)$ between level of urban development and household trip generation. With coefficient of determination $\left(r^{2}\right)$ of $0.56,56 \%$ of variation in household trip generation in Ogun state is explained by level of socio-economic development of cities. This suggests the needs to be critical in using socio-economic characteristics of residents alone as measures of determinants of household travel behavior as done in several previous studies in transport research.
\end{abstract}

Key words: Intra-urban, trip generation, Socio-economic development, urban centers, Nigeria, Ogun State.

\section{Introduction}

Cities all over the world are characterized by a set of activities which account for the concentration of people in them. Such activities may include those arising from manufacturing trading and finance, transportation and tertiary sectors. All these combine to generate the spatial configuration of the city because their requirements are sometimes functionally differentiated and also spatially segregated. The spatial segregation of urban land-use type creates spatial imbalance and this necessitates spatial interaction for functional inter relationships. In other words, urban areas are associated with complex development and this is accompanied by intricate patterns of movement (Aderamo, 2004; Solanke, 2005, 2013).

In several cities living accommodation and places of other activities such as work, school, recreation etc are no longer in close proximity. People live long distances from their places of wok and travel everyday using any of transport modes. In other words, in this modern time, people travel prodigious distance either within or between cities to fulfill their needs for necessities and or luxuries (Oyesiku, 2003; Sumaila and Adetunji, 2004; Solanke, 2005).

Human travel represents an expression of an individual's behavior and as such it has the characteristics of being habitual. As a habit, it tends to be repetitive and the repetition occurs on definite pattern (Bruton, 1975).

The trip generation in urban centers logically is a function of complex interaction of socio-economic characteristics of urban centers and those of their residents (Oyesiku, 1990; Hanson and Schwab, 1995; Solanke, 2005). However, past works have demonstrated the influence of socio-economic characteristics of urban residents on urban travel behavior while a lot of lip-service has been paid to the importance of the effect of socio-economic characteristics of urban centers. Infact, the relative importance of the hierarchy of urban system in the explanation of travel pattern is more often than not ignored in urban transport studies.

This study is therefore designed to contribute to the existing knowledge in urban 
transport studies by examining the influence which socio-economic characteristics of urban centers have on urban travel pattern. In order to do this, the causal relationship between household travel and socio-economic level of development of urban centers is established and its implications for urban transport planning are analyzed.

\section{Study Area}

\section{Geographical Location}

The study area, Ogun state is one of the fast developing states in Nigeria. It lies in the south western part of the country within latitudes $6^{0} \mathrm{~N}$ and $8^{0} \mathrm{~N}$ and Longitudes $3^{0} \mathrm{E}$ and $5^{\circ} \mathrm{E}$.

The state is bounded on the west by the Republic of Benin and on the east by Ondo state. To the north is Oyo state while Lagos state and the Atlantic Ocean are to the south (Figure 1). The state covers about 16,762 square kilometer which is approximately 1.81 percent of Nigeria's land mass.

\section{Geology and Relief}

The geology of the state comprises the sedimentary and basement complex rocks. According to Akanni (2000) about 1,200 $\mathrm{km}^{2}$ of the state is of sedimentary formation while about $400 \mathrm{~km}^{2}$ is of basement complex rocks of pre-cambrian formation. The relief of the state, like other parts of the country is more or less coinciding with the major rock types.

There are two main relief regions: First, the creeks and Lagoons forming a small section in the south eastern part of the state, the altitude of which ranges from 0 to 40metres above sea level. Second, the undulating coastal plain and the low lands with the elevation increasing northwards from about 30 to 250 meters above sea level. The plain is broken by sandstone cresta especially towards the western part of the state. There are pockets of rock outcrops dotting the landscape especially around the state capital (Abeokuta). The whole state is drained by flowing coastal rivers such as Ogun, Yewa and Shasha from Oyo state through the thickly vegetated western part of the state. Numerous small rivers and streams are at the south eastern parts flowing perennially through the swampy terrain.

\section{Climate and Vegetation}

The state is within the tropical humid climatic zone of Nigeria, which is generally characterized by high rainfall and high relative humidity. This is attributable to the prevalence of moisture laden tropical maritime air mass over the state for about nine months in a year. The mean relative humidity varies from $66.2 \%$ in January to $88.4 \%$ in July (Akanni, 2000).
The rainfall shows a double-maxima distribution reaching the peak during the months of June and September. The average monthly rainfall for the state ranges between $7.1 \mathrm{~mm}$ in the month of January to $208.27 \mathrm{~mm}$ in the month of June. The mean annual temperature is $26^{\circ} \mathrm{C}$; although with some variations over time. The mean diurnal minimum temperature varies from $21.8^{\circ} \mathrm{C}$ in December to $24.34^{\circ} \mathrm{C}$ in April while the mean diurnal maximum temperature varies from $33.92^{\circ} \mathrm{C}$ to $37.1^{\circ} \mathrm{C}$ at the onset of the wet season (March and April) (Akanni, 2000).

On the basis of climatic features, the state is characterized by two distinct weather seasons: the wet and dry. The wet season marked by lower mean temperature, higher total rainfall and higher relative humidity is usually experienced between the months of February and October. However, little dry season is sometimes experienced in August, a phenomenon characterized by drastic reduction in the frequency and intensity of rainfall and referred to as 'August break'. The dry season sets in by November and persists till the end of January. It is usually accompanied by harmattan cold, brought by the prevailing north-west winds.

In terms of vegetation, the state can be divided into three distinctive zones. Where the state shares a boundary with the Atlantic Ocean, the vegetation is of a swampy type with mangroves and other edaphic trees. There is also rainforest vegetation in some sections of the state while the state capital (Abeokuta) and some areas are characterized by derived forest vegetation, having been altered by human activities.

\section{Socio-Economic Activities}

In the pre-colonial era, the economy of the state, like those of most other traditional Nigerian towns was characterized by farming, craft production, trade and town administration (Oyesiku 1990, Ademiluyi 1996).

The establishment of colonial rule in the state brought new forms of economic activities which are characteristics of western economy, and there have also been some modifications to the traditional system of production. Thus, several identifiable modern economic activities including banks, insurance houses, modern and traditional markets, petrol stations, motor companies, commercial enterprises, light and heavy industrial organizations are now found in different urban centres in varying degrees.

Some settlements, especially the capital (Abeokuta) benefited immensely from their 
early contact with the European population (the missionaries) who helped in the development of such areas by establishing mission houses, schools, churches, dispensaries and hospitals.

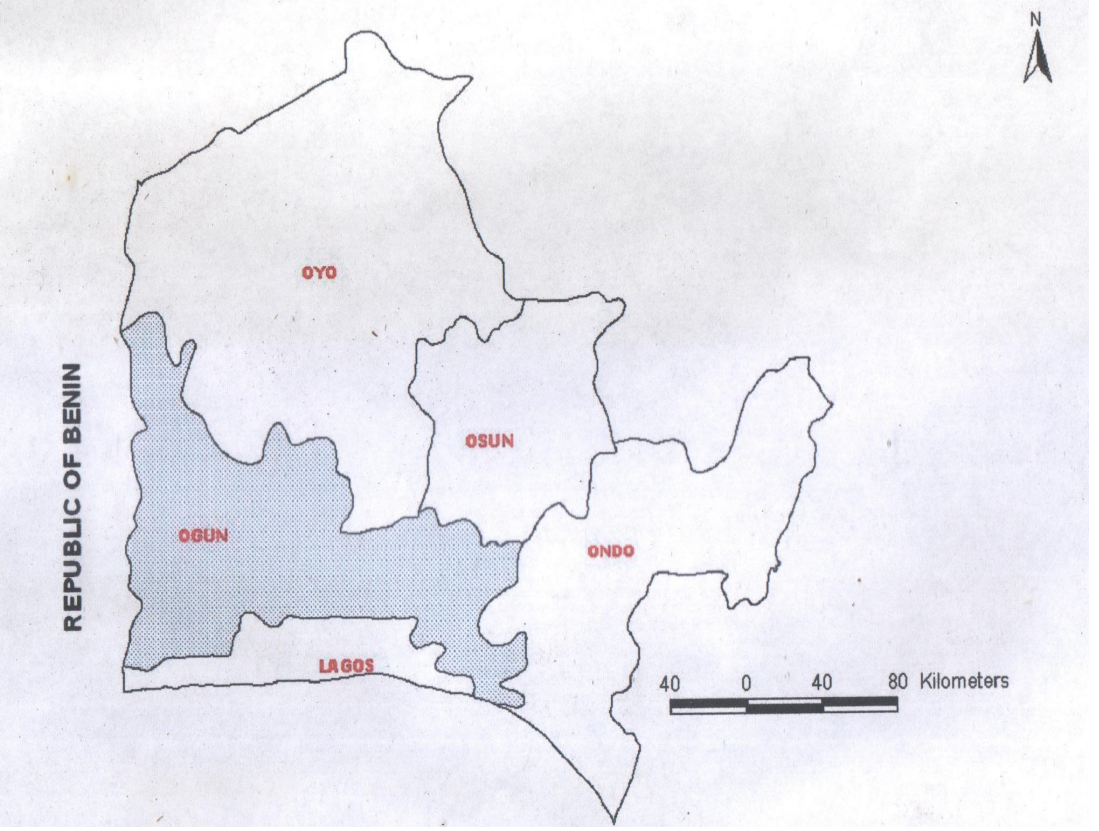

Figure 1: Ogun State and its neighbours

Agriculture, the mainstay of the economy provides the major single occupation for the people of the state especially those in the rural areas. Arable crops like maize, yam, cassava, rice, cocoyam, groundnut, melon, banana, plantain, oranges pineapple, sugar-cane and Kolanuts are produced in the state. The major export crops produced are cocoa, coffee, rubber and palm kernel. In the riverine areas, people engage in extensive fish farming. Lumbering activities also thrive because the state is endowed with appreciable forest resources. This perhaps accounts for the high number of sawmills in the state.

Another major economic activity in the state is extensive trading and light commercial merchandising. The people engage in buying and selling of all types of goods ranging from local household utensils to food, beverages and manufactured goods.

The industrial sector constitutes another economic activity. Among the major industrial types in the state are: food, beverages and tobacco, textile, wearing apparel and products, fabricated metal products, wood and wood products, chemical products, pulp, paper products, printing and publishing, non-metallic minerals, motor vehicles and miscellaneous assemblies, domestic/ industrial plastic and rubber products and electrical and electronics (Odugbemi,1993). The potentials of the state for industrial development are as a result of her natural, agricultural and forestry resources and proximity to Lagos and Ibadan (Odugbemi 1993, Odugbemi and Solanke 1997). People in the state also engaged in paid employment of the local, state and federal government agencies. Others engage in business activities which are dominated by distributive trade, personal services, transportation, finance and insurance services.

To complement the socio-economic development of the state are education, health, telecommunication, postal and insurance institutions and other socio-economic services and infrastructures that exist in many cities. For instance, the state has about 1424 public primary schools, 474 public secondary schools, 7 Government Technical College, 1120 registered private nursery and primary schools 257 registered private secondary schools, 2 colleges of education, 4 polytechnics, 3 public universities, and 8 private universities.

Also, there are 88 hospitals/clinics, 210 maternity centres, 202 dispensaries, 16 comprehensive/primary health centres, 4 dental centres and 1 university teaching hospital. Notable tourist attractions in the state are Olumo rock at Abeokuta, Birikisu sungbo shrine at Oke-eri, Ebute-oni beach, Oronna shrine and the celestial city at Imeko (Odubgemi and Solanke, 1997).

\section{Methodology}

Both secondary and primary data were used in this study. The secondary data relate to the factors of growth of urban centers. In other words, they relate to the socio-economic variables or development indicators of the urban centers. Various government publications 
on Ogun state such as the states statistical year book and abstract of statistics, local government digests; technical reports, academic journals and other periodic publications of Ogun state ministry of finance and economic planning provided the bulk of secondary information for this study. The federal office of statistics and national population commission also provided some information on the population figures of the cities.

In the literature, little agreement exists on the range of indicators to be included in the measurement of development level of an area unit. A review of research works on regional development in the developing societies for instance reflects the concatenation of social and economic variables in various forms (Onyemelukwe 1978, 1981 Oyebanji, 1981, Abumere 1987, Ghaffar, 1987, Tanimowo 1988, Oyesiku 1990, Ademiluyi 1996, Solanke 2005) among others, and thus, serves as antecedents to this study.

In all, seven groups of variables considered paramount and crucial enough to reflect the variation in the level of socio-economic development of cities were selected. They are:

1. The geographical extent (population sizes and number of rate able hereditaments)

2. Educational institutions (nursery and primary, secondary and post-secondary schools)

3. Health services (public and private hospitals and specialist clinics)

4. Shopping facilities (number of daily and regional markets)

5. Large scale industrial establishments (the number with 50 or more employees)

6. Communication facilities (number of telephone lines, post offices and postal agencies).

7. Recreational and sporting facilities (number of stadia, hotels, sporting and recreational facilities).

These facilities and services were chosen because they were measurable, relatively available and they have been recognized as measures of urban socio-economic growth (Filani 1972, Oyebanji 1981, Oyesiku 1990, Ademiluyi 1996). They are, therefore considered as potentials of urban trip generation.

The primary source of data is questionnaire survey for urban residents on household basis. Following the works of Ogunjumo (1986) Oyesiku (1990) Dimitriou (1995) and Solanke (2005) household is a well-known key decisionmaking unit for the general movement pattern and constitutes the major point of origin of urban travel. An urban centre is defined as the settlement with a total population of 20,000 people or more in conformity with United Nations and the definition of urban centre in the Nigeria national population census of 1963 and 1991. Based on this definition there are 22 urban centres in the state. 14 of these in different categories (such as large, medium and small) in terms of population sizes were randomly selected. They are: Abeokuta, (the state capital), Ijebu-ode, Sagamu, Ilaro, AgoIwoye, Ota, Ijebu-Igbo, Ayetoro, Ifo, Iperu, Ado-Odo, Idi-Iroko, Owode-Yewa and Alagbado.

A household survey was conducted in each urban centre to generate data on urban travel. Each urban centre was divided into residential quarters along the demarcation of the town into residential neighborhoods by the zonal town planning authorities (ZTPA). In each of the neighborhoods, random selection of streets and systematic sampling of the housing unit were made. The size of the household interviewed was based on the estimate for each urban centre.

There were about 269, 095 households in all the selected urban centres out of which 1,507 were sampled in proportion to the number of households in each city (Table 1). 1,300 fully completed copies of the questionnaire were used in this study

Table 1: Urban Centres in Ogun State, Estimated number of Households and Sample Sizes

\begin{tabular}{llll}
\hline S/NO & $\begin{array}{l}\text { Urban } \\
\text { Centre }\end{array}$ & $\begin{array}{l}\text { Estimated } \\
\text { number of } \\
\text { Households }\end{array}$ & $\begin{array}{l}\text { Household } \\
\text { Sample size }\end{array}$ \\
\hline 1. & Abeokuta & 89.263 & 500 \\
2. & Ijebu-ode & 31,459 & 176 \\
3. & Sagamu & 32,268 & 181 \\
4. & Ilaro & 9,850 & 55 \\
5. & Ago-Iwoye & 7,498 & 42 \\
6. & Ota & 26,149 & 146 \\
7. & Ijebu-Igbo & 16,430 & 92 \\
8. & Ayetoro & 7,633 & 43 \\
9. & Ifo & 13,273 & 74 \\
10. & Iperu & 5,854 & 33 \\
11. & Ado-Odo & 5,830 & 33 \\
12. & Idi-Iroko & 4,654 & 26 \\
13. & Owode & 9.958 & 56 \\
14. & Alagbado & 8,976 & 50 \\
Total & & 269,095 & 1,507 \\
\hline
\end{tabular}

Source: Estimates extracted from Ministry of Finance and Economic Planning (Statistics Division) Abeokuta, Ogun State. 
The questionnaire dealt among others with trip generation in each urban centre on household basis.

\section{Technique of Analysis}

The level of development of urban centres was established through average proportion of aggregate socio-economic variables in each city. This was estimated through summation of percentage scores of urban centre on development variables and then divided by the number of variables considered

Symbolically, it is estimated as follow:

$$
\alpha=\frac{\sum_{j=1}^{n} X j}{N}
$$

Where:

$\alpha=$ Level of Socio-economic characteristics/development of a city

$\mathrm{Xj}=$ Percentage scores of a city in Socioeconomic variables

$\mathrm{N}=$ Number of Socio-economic variables considered

Following the works of Nacer (1979), Ghaffar (1987) Ademiluyi (1996) and Solanke (2005) the level of development of urban centres provides a means to rank and classify the cities on a common measure or scale. It also provides the basis against which variations in development levels attained can be visualized and compared.

The measure of central tendency (arithmetic mean) was used to establish the average household trip generation (frequency of trip) for each urban centre. Spearman rank correlation technique was later applied to establish the nature and extent of relationship between the level of development of urban centers and frequency of household trip generation. Spearman rank correlation was employed because the urban centers were ranked on the basis of their performance on each of the two variables for comparative analysis and the ranked values for each of the cities constitute the data for the correlation analysis.

\section{Results and Discussions}

The percentage distribution of aggregate socio-economic variables among urban centre of Ogun State and the subsequent ranks of these cities in the hierarchical structure of urban development are presented in table 2 .
Table 2: Ranking of Urban Centres According to Percentage Distribution in Aggregate SocioEconomic Variables

\begin{tabular}{lll}
\hline $\begin{array}{l}\text { Urban } \\
\text { Centres }\end{array}$ & $\begin{array}{l}\text { Percentage Distribution } \\
\text { in Aggregate Socio - } \\
\text { economic Variables }\end{array}$ & $\begin{array}{l}\text { Rank of } \\
\text { Urban } \\
\text { Centre }\end{array}$ \\
\hline Abeokuta & 31.22 & $1^{\text {st }}$ \\
Ijebu-Ode & 14.41 & $2^{\text {nd }}$ \\
Sagamu & 10.33 & $3^{\text {rd }}$ \\
Otta & 9.88 & $4^{\text {th }}$ \\
Ilaro & 7.37 & $5^{\text {th }}$ \\
Ijebu-Igbo & 5.08 & $6^{\text {th }}$ \\
Ifo & 4.96 & $7^{\text {th }}$ \\
Ago-Iwoye & 4.06 & $8^{\text {th }}$ \\
Ayetoro & 3.37 & $9^{\text {th }}$ \\
Iperu & 2.27 & $10^{\text {th }}$ \\
Alagbado & 1.94 & $11^{\text {th }}$ \\
Ado-Odo & 1.80 & $12^{\text {th }}$ \\
Idi-Iroko & 1.46 & $13^{\text {th }}$ \\
Owode & 1.36 & $14^{\text {th }}$ \\
Total & 100 & \\
\hline
\end{tabular}

On the aggregate, Abeokuta has an average of $31.22 \%$ to occupy first position on the development ladder. The second urban centre on the development ladder is Ijebu-Ode with a distant aggregate average of $14.41 \%$. Sagamu, Ota and Ilaro occupy $3^{\text {rd }}, 4^{\text {th }}$ and $5^{\text {th }}$ positions respectively. The last on the development ladder is Owode with aggregate average of less than $2 \%$. The above findings show that Abeokuta dominates all other urban centre in the distributions of socio-economic variables. This is attributable to its status as the state capital as well as administrative headquarters of two local governments.

The development pattern of the state can therefore be described as a dualistic structure of both privileged and underprivileged cities and this has the potentials to influence trip generation across the cities. The frequency of household trips in urban centers of Ogun State is presented in Table 3. Frequency of travel is defined in this study as the average trips generated by individual households in urban centers for one week. This is estimated by dividing the total trips generated by households in a city for various purposes within one week by the number of households sampled in the city. At the regional level, averages of 42 trips are generated per household per week (Table 3). 
Table 3: Average frequency of Household trips per week in urban centres of Ogun state

\begin{tabular}{ll}
\hline Town & $\begin{array}{l}\text { Trip Frequency Per } \\
\text { Household Per } \\
\text { week }\end{array}$ \\
\hline Abeokuta & 48.60 \\
Ijebu-Ode & 42.74 \\
Sagamu & 44.81 \\
Ilaro & 35.33 \\
Ago-Iwoye & 39.83 \\
Ota & 41.30 \\
Ijebu-Igbo & 40.49 \\
Ayetoro & 33.27 \\
Ifo & 32.92 \\
Iperu & 30.33 \\
Ado-Odo & 25.18 \\
Idi-Iroko & 31.42 \\
Owode & 32.98 \\
Alagbado & 40.77 \\
Regional Level & 42.28 \\
\hline
\end{tabular}

Thus, urban centers such as Abeokuta, Sagamu and Ijebu-Ode with average household trips of 49, 43, and 43 trips per week respectively, generate higher trips than the regional average. These large-sized urban centers generate more trips than others in the state; and this can be explained by the differences in level of socioeconomic facilities of the urban centers. For instance, Abeokuta, Ijebu-ode and Sagamu which constitute the first three urban centers in the hierarchy of urban development in the state also emerge as the first three cities on aggregate level of trip generation.

The relative high frequency of trip per household per week for urban centers like Ota (41), Alagbado, (40) ijebu-Igbo (40) and AgoIwoye (39) is equally noteworthy. The relative high frequency of trip generation in Alagbado and Ota can be explained by reasons of their proximity to Lagos, while that of Ijebu-Igbo and Ago-Iwoye can be explained by reason of being university towns. The spread-effect from Lagos (the business and commercial nerve center of the nation) might have influenced the level of socio-economic facilities in the nearby settlement of Alagbado and Ota and thus, serve as potentials for trip generation. In the same manner, university towns like Ijebu-Igbo and Ago-Iwoye over the years have attracted large number of service ventures, business opportunities which cater for the students of Olabisi Onabanjo University which is a nonresidential institution. These service ventures and business opportunities serve as potentials for trip generation in these cities.

In line with the focus of the study, spearman rank correlation technique is used to examine relationship between socio-economic development of cities and household frequency of trip generation (Table 4).

Table 4: Ranks of Urban Centres on the Basis of Frequency of Trips Generated and Level of Development

\begin{tabular}{lllll}
\hline Town & $\begin{array}{l}\text { Household Average } \\
\text { Trip Per Week (Y) }\end{array}$ & Rank of $y$ & $\begin{array}{l}\text { Level of Socio-Economic } \\
\text { Development }(\mathrm{X})\end{array}$ & Rank of $\mathrm{x}$ \\
\hline Abeokuta & 48.60 & 1 & 31.22 & 1 \\
Ijebu-Ode & 42.74 & 3 & 14.41 & 2 \\
Sagamu & 44.81 & 2 & 10.33 & 3 \\
Ilaro & 35.33 & 8 & 7.37 & 5 \\
Ago-Iwoye & 39.83 & 7 & 4.06 & 8 \\
Ota & 41.30 & 4 & 9.88 & 4 \\
Ijebu-Igbo & 40.49 & 6 & 5.08 & 6 \\
Ayetoro & 33.27 & 9 & 3.37 & 9 \\
Ifo & 32.92 & 11 & 4.96 & 7 \\
Iperu & 30.33 & 13 & 2.77 & 10 \\
Ado-odo & 25.17 & 14 & 1.80 & 11 \\
Idi-Iroko & 31.42 & 12 & 1.46 & 13 \\
Owode & 32.98 & 10 & 1.36 & 14 \\
Alagbado & 40.77 & 5 & 1.93 & 12 \\
\hline
\end{tabular}

ryx $=0.75, \mathrm{p} \leq 0.01, \mathrm{r}^{2} \mathrm{yx}=0.56$

With, ryx $=0.75, \mathrm{p} \leq 0.01$, there exists a high, positive and significant relationship between socioeconomic development and household frequency of trip in urban centers of Ogun State.

With co-efficient of determination $\left(\mathrm{r}^{2} \mathrm{yx}\right)$ of $0.56,56 \%$ of the variation in household intracity trips in Ogun State is explained by variation in the level of socio-economic development of urban centers. Urban components of Ogun state no doubt exhibits a remarkable variation in distribution of socioeconomic facilities and household frequency of trip. The high positive relationship between urban development and household intra-city trip 
generation shows that the higher the level of urban socio-economic development the higher the frequency of household trip generation.

This finding constitutes a great challenge to previous studies in transport geography especially those on urban travel. Hitherto, socio-economic characteristics of urban residents are considered as major determinants of urban trip generation. However, this study has shown that subsequent research in transport geography needs to be critical in using socioeconomic characteristics of residents alone as measures of determinants of household travel behavior. Indeed, socio-economic developments of urban centre should be given priority attention in an attempt to structure commuting in urban centres especially in the developing world. Every additional necessary socio-economic facility in urban centres must take into consideration its implication for trip generation to ensure smooth and crisis-free interaction within urban centre.

\section{Conclusion}

The influence of socio-economic development of urban centers on intra-city travel in Ogun State, Nigeria is examined in this study. There is remarkable variation in distribution of socio-economic facilities across the urban centers and same thing goes for household frequency of trip. Abeokuta, the State capital with aggregate proportion of $31.22 \%$ of socio-economic facilities occupies the first position in hierarchy of urban development in the state. This is followed by Ijebu-ode with a distant aggregate of $14.41 \%$ while other cities follow with varying distance aggregate. In a similar perspective, Abeokuta with average household trip frequency of 49 per week dominates in household trip generation. Ijebu-ode and Sagamu also follow, with each generating an average of 43 trips per household per week.

There is a significant high positive correlation (ryx $=0.75, \mathrm{p} \leq 0.01$ ) between urban development and household intra-city trip generation. With $\mathrm{r}^{2}=0.56,56 \%$ of the variation in household intra-city trip generated is explained by level of socio-economic development of urban centers. This finding is important not only to the goal of this study, but also to researchers in transport studies. Hitherto, urban geographers and transport planners tend to rely heavily on Socio-economic characteristics of residents in their explanation of urban travel behavior. However, the high positive relationship observed between hierarchy of development and trip generation in urban centers shows that researchers need to be critical in using socio-economic characteristics of residents alone as measures of determination of household travel behavior in developing nations.

\section{References}

Abumere, S. I. (1987). "So the Rich Areas Get even Richer, some Meditations on the Duality in the space-Economy of Nigeria". Faculty of Social Sciences Lecture, University of Ibadan.

Ademiluyi, I.A. (1996). An Analysis of Spatiotemporal patterns of inequalities in Ogun State, Nigeria, Unpublished Ph.D Thesis, University of Ibadan.

Aderamo, A.J. (2004). 'Planning for Urban Transportation in Nigeria in Vandu Chikolo I; Ogunsanya A. A and Sumaila, A. G. (eds) (ed) Perspectives on Urban Transportation in Nigeria, NITT Zaria, Pp. 312-331.

Akanni, C.O. (2000). 'Physical Environment' in Onakomaiya, S.O., Odugbemi O. O., Oyesiku, O.O. and Ademiluyi I. A. (eds) Ogun State:Local and Regional Perspectives,Centre for Sandwich Programmes (CESAP) Ogun State University, Ago-Iwoye. Pp.14-26

Bruton, M. (1975). Introduction to Transportation Planning Hutchinson, London.

Dimitriou, H.T. (1995). A Developmental Approach to Urban Transport Planning: An Indonisian Illustration: Ashgate Publishing Limited, Avebury.

Filani, M.O. (1972). "Changing Patterns of Central Places and Functional Regions: Temporal and Spatial Dynamics of Air Traffic Flows in the United States". Unpublished Ph.D Thesis, Penn state University USA.

Ghaffar, F.A. (1987). "Regional Inequalities and Development in Peninsular Malaysia" Malaysian Journal of Tropical Geography, 16: 21-36.

Hanson, S and Schwab, M. (1995). "Describing Disaggregate Flows: Individual and Household Activity Patterns" in Hanson, S. (ed) The Geography of Urban Transportation $\left(2^{\text {nd }}\right.$ edition), The Guilford press, New York, Pp. 166-187.

Nacer, M. (1979). 'Regional Development in Algeria, Unpublished M.A. Dissertation, University of Sheffield, England 
Odugbemi, O.O. (1993). 'Ogun state' in Udo R.K. and Mamman, D.(eds) Nigeria: Giant in the Tropics, Gabumo press Lagos, Pp.349-362.

Odugbemi, O.O. and Solanke, M.O. (1997). 'The Geographical Region, Setting, Structure and Impact of the Ogun State University' in Odugbemi, O.O. Balogun,K.A. Adebanjo A, and Adedoyin, S. F.(eds) Essential of General Studies, Vol 1, Centre for Sandwich Programmes (CESAP) Ogun State University, Ago-Iwoye, Pp 20-41.

Ogunjumo, A. (1986). "The Pattern of trip generation at Ile-ife", Journal of Nigerian Institute of Town Planners. VI and VII, 99-144.

Onokerhoraye, A.G. and Omuta, G.E.D. (1986). Regional Development and Planning. The Geography and Planning Series of Study Notes, University of Benin, Benin City.

Onyemelukwe, J.O.C. (1981). Socio-Economic Indicators of Development in Nigeria, Monograph Series No. 1 Development of Geography, University of Ibadan.

Oyebanji, O. J. (1981). "Regional Inequalities in Economic Growth and Development: A case study from Nigeria" Journal of the Nigerian Institute of Town Planners, 11, 71-85

Oyesiku, O.O. (1990). "Inter-Urban Travel Patterns in Nigeria: A Case study of Ogun State". Unpublished Ph.D Thesis, University of Benin, Nigeria.

Oyesiku, O.K. (2003). "Sustainable Transportation Strategies for Intermediate
Cities in Nigeria" Journal of the Nigerian Institute of Town Planners, XVI, Pp. 3544.

Solanke, M.O. (2005). "Spatial analysis of intra-urban travel patterns in Ogun State". An Unpublished Ph.D Thesis, University of Ibadan.

Solanke, M.O. (2013). "Intra-Urban work and school trips characteristics in Ogun state, Nigeria" International Journal of Development and sustainability, Vol. 2 No. 2, (In Press).

Sumaila, A. and Adetunji, R. (2004). "Future Perspectives in Urban transportation" in Vandu-Chikolo, I., Ogunsanya, A.A. and Sumaila, A.G. (eds) perspectives on Urban Transportation in Nigeria, NITT Zaria, Pp. 370-381.

Tanimowo, N.B.N. (1988). "Regional Polarisation and Socio-Economic Deprivation: A study of spatial Inequalities in Oyo State of Nigeria". Unpublished Ph.D Thesis, Department of Geography, University of Ibadan, Ibadan, Nigeria.

Vandu-chikolo, I. (2004). 'Urban Transport Infrastructure' in Vandu-Chikolo, I. Ogunsanya, A.A. and Sumaila, A.G. (eds) perspectives on Urban Transportation in Nigeria, NITT, Zaria Pp. 70-86.

Vandu-Chikolo, I. and Ogunsanya, A.A. (2004). 'Conclusion: where do we go from here?' in Vandu-chikolo, I., Ogunsanya, A.A. and Sumila, A. G. (eds) Perspectives on Urban Transportation in Nigeria, NITT, Zaria, Pp. 382-388. 